\title{
Analysis on the Cognition of Students and Main problems in Green Campus Construction in Northern Universities
}

\author{
Shanling Jiang \\ Tianjin Polytechnic University \\ College of Economics \\ Tianjin
}

\author{
Hong Zhao* \\ Tianjin Polytechnic University \\ College of Economics \\ Tianjin
}

\author{
Hong Jiang \\ Tianjin Polytechnic University \\ College of Economics \\ Tianjin
}

\begin{abstract}
To seek for main problems in the green campus construction, the paper is based on the questionnaire survey of panel data, using SPSS20.0 to study students' cognition on green campus and main factors influencing the green campus construction. Comparing with others' studies, our survey is not focused on college managers but college students instead. And results shows that campus planning, the behavior of others, student education and student consciousness account for $\mathbf{7 1 . 9 \%}$, $77.2 \%, 85.7 \%$ and $72.8 \%$ in the respective principal component, which need to be improved urgently.
\end{abstract}

Keywords-Green campus; College students' perspective; Principal component analysis; Problems

\section{BACKGROUND}

As the social economy developed, problems of survival and development of human beings were gradually increasing. Environmental problems such as frequent smog, water pollution and carbon emissions had prompted people to reflect deeply on their own behavior. It was under the background where the international community had paid close attention to environmental issues that our country university campus did a useful attempt on green campus concept, which embodied the concept of sustainable development in the concrete application of the campus construction.

As early as 1972, the idea of "green school" was put forward on the Stockholm conference on human environment. ${ }^{[1]}$ In October 1990, the presidents of twenty famous schools in the world come up with the Talloires Declaration in Talliores, France, which marked the beginning of the construction of "green campus",[2]. In the late 20th century, the concept of "green campus" was formally introduced into the China and recognized. ${ }^{[3]}$ In June 1998, Tsinghua University first put forward the proposition of establishing "Green University" in China, and submitted a concrete construction plan of "establishing green demonstration project" to the State Environmental Protection Bureau. ${ }^{[4]}$ The Green Campus Evaluation Standard was promulgated in China in April

The paper has been sponsored the Green Campus Evaluation Research Project of Green Development Research Foundation from the Ministry of Education (LZFZ1601).
2013(CSUS/GBC 04-2013), which defined the green campus as a way to maximize resource savings (energy saving, water saving, material saving, land conservation), protect environment and reduce pollution in order to provide teachers and students with a healthy, applicable, efficient teaching and living environment. ${ }^{[5]}$

The green campus has distinct characteristics: first, different from the ordinary campus, its purpose is to pursue the harmonious coexistence of campus and nature, to make efforts to match artificial environment with natural environment effectively, and to reduce negative externality. Then, compared with the green ecology, it pays attention to the greening of the social environment and seeks to put the concept of sustainable development into all aspects of social life. Finally, compared with the green city, it not only makes it possible to take advantage of technology and research capacity to explore the optimal campus development path, but also expands the influence through the flow of college students. ${ }^{[6]}$

At present, there is much literature on green campus at home and abroad, which has some positive influence on the green campus construction. However, a great deal of literature does research on reasonable planning, infrastructure construction and campus evaluation system from the perspective of campus managers, which neglects the main body of green campus -- college students. College students are not only the direct beneficiaries of green campus, but also the green campus participants, who have great influence in the green campus construction. Therefore, this paper will analyze and study main factors and some problems in the construction with the help of questionnaire survey from the perspective of college students.

\section{QUESTIONNAIRE DESIGN}

\section{A. Purpose of questionnaire design}

This questionnaire takes college student as the main body, and studies the factors of the green campus construction. On 
the one hand, it is aimed at having a preliminary understanding of the northern campus university students' thought and the current situation of the green campus construction, and finding problems in the green campus construction. On the other hand, college students are expected to learn more about the green campus, adhere to the green concept, form the green thinking, identify with the green campus, and become the main force in the green campus construction.

\section{B. Questionnaire design procedure}

First, determine the subject and subject of the questionnaire. The topic of the paper is the survey of green campus in the north, and the main body is the college students. Second, collect the relevant research topics, collate and sum up five blocks of research, namely: basic information, the understanding of the green campus, the behavior of the green campus, campus evaluation and the outlook of the green campus. Third, expand the content of the plate and design the issues scientifically. Finally, determine the type of survey methods. This questionnaire is distributed in online, which can make it easy to collect the information of the northern campus in a wide range.

\section{Content of questionnaire design}

Involving a total of 36 minor issues, the content of the questionnaire includes five parts: the first part of the questionnaire is about the basic information of college students, which involves 3 issues; The second part is the understanding of green campus, including 4 issues; The third part is to study the behavior about green campus, divided into 10 issues; The fourth part is to evaluate the former or present campus, involving 10 issues; The last part is the outlook on the green campus, covering 9 issues.

\section{QUESTIONNAIRE SURVEY RESULTS}

A total of 380 questionnaires are distributed in this study. Because of the phenomenon of information asymmetry in the online questionnaires, 50 unqualified questionnaires are eliminated and 330 valid questionnaires are recovered. The effective rate of recovery is about $87 \%$, and so the results are effective. The following five parts of the questionnaire will be analyzed and studied one by one.

\section{A. Personal information}

There are 124 male respondents (37.58\%) and 206 female respondents (62.42\%) in the questionnaire. The regions are mainly Beijing, Tianjin, Hebei, Henan, Shanxi, Liaoning, Jilin, Gansu, Inner Mongolia, Xinjiang and other provinces, cities, or autonomous regions. Tianjin accounts for a large proportion, covering $62.12 \%$. Shanxi Province is second with $13.94 \%$, and other provinces or municipalities are smaller. Due to the concentration of respondents in the northern region, where there is a certain similarity between the environment and the development model of the campus, the regional distribution is less affected by the survey results.

As for the educational structure of respondents (TABLE I), it can be seen that the majority of respondents are undergraduate students, with a total number of 157 . The number of bachelor's degree is similar to that of graduate students, accounting for $21.82 \%$ and $26.96 \%$ respectively, while the number of graduate students and above is the least, reaching $3.64 \%$ of the total.

TABLE I. THE EDUCATIONAL STRUCTURE OF THE RESPONDENTS

\begin{tabular}{|c|c|c|}
\hline Educational background & $\begin{array}{c}\text { Number of } \\
\text { persons }\end{array}$ & Percentage \\
\hline undergraduate & 157 & $47.58 \%$ \\
\hline Bachelor's degree & 72 & $21.82 \%$ \\
\hline Graduate students & 89 & $26.96 \%$ \\
\hline Graduate degree or above & 12 & $3.64 \%$ \\
\hline Total & 330 & $100 \%$ \\
\hline
\end{tabular}

\section{B. Understanding of green campus}

TABLE II shows college students' familiarity with the importance of green campus. First of all, from the level of familiarity, there are only 14 respondents who know very well, and the number of the unfamiliar and the unknown is 241 . Secondly, from the view of the importance of green campus, 315 college students think its influence is very large or larger, and only 15 respondents think it small or no. Finally, from these two aspects, it can be described that the green campus has great influence but few college students have good understanding of it.

TABLE II. COLLEGE ST UDENT S’ UNDERST ANDING OF GREEN CAMPUS

\begin{tabular}{|c|c|c|c|c|c|}
\hline $\begin{array}{c}\text { Familiarity } \\
\text { degree }\end{array}$ & more & large & less & no & total \\
\hline well understand & 10 & 3 & 0 & 1 & 14 \\
\hline understand & 41 & 34 & 0 & 0 & 75 \\
\hline $\begin{array}{c}\text { Little } \\
\text { understand }\end{array}$ & 98 & 99 & 6 & 3 & 206 \\
\hline No understand & 17 & 13 & 3 & 2 & 35 \\
\hline Total & 166 & 149 & 9 & 6 & 330 \\
\hline
\end{tabular}

What' more, regarding the access to green campus related knowledge, the number of respondents who get knowledge on the Internet, reaching about half of the total number, which is slightly higher than the total number of people on campus and other means combined.

\section{Behavior related to green schools}

Behavior of the green campus shows the details of the daily behavior habits of college students. Whether behavior of the college students accord with the purpose of the green campus is directly related to the achievements of the green campus construction. There are many problems involved in the design, so the green behavior can be divided into the self-conscious behavior of college students and the advocacy behavior of the school or college student organization.

From the survey, it can be made a conclusion that most of respondents have the consciousness to protect the environment, and often consciously save resource and protect the environment. The number of respondents who consciously lose 
garbage is 326, accounting for $98.48 \%$ of the total; 293 respondents consciously save paper, reaching 88.79\%; 302 respondents voluntarily save electricity, up to $91.52 \%$. What's more, 321 respondents are willing to save water, at $97.27 \%$, while 280 respondents carry out battery recovery on a voluntary basis, achieving $84.85 \%$ of the total.

When it comes to advocating behavior, the result is not satisfactory. A large proportion of respondents choose to ignore it. When the school or the college student organization advocates the activity, respondents do not behave very enthusiastically. In addition, some advertising signs do not greatly persuade college students.

\section{Evaluation of campus}

As the relevant information is collected by means of questionnaire survey, the grasp of the construction status of green campus is mainly obtained from college students' evaluation of campus.

Firstly, it can be seen that respondents' overall view is optimistic, and the number of respondents who are satisfied with the green activities promoted by school or student organization is 220. Secondly, 101 respondents are satisfied with the introduction of environmental protection courses in schools, and the dissatisfied is 229. Thirdly, as for the watersaving facilities in schools, 253 respondents are satisfied, covering $76.7 \%$ of the total surveyed, which shows that most universities have done well in saving water, and only a small number of them need to be improved. Finally, as far as campus planning and campus water quality are concerned, most respondents still have positive views on campus planning and have negative attitude towards school water quality. Mainly because the colleges to which the respondents belong are located in the north, where there is a fragile ecosystem and water quality is generally difficult to ensure.

According to the evaluation of others, respondents' attitudes towards other respondents' water conservation are different, basically flat. 186 respondents are satisfied, and 144 respondents have negative views. However, 321 respondents saved water, while 9 respondents did not save water. This can to some extent indicate that 135 respondents may have not only strict with themselves, but also very strict with other people's water saving behavior.

As to the use of disposable tableware in the canteen, there is no demand, there is no consumption. The reason why most respondents are dissatisfied is that many college students have used disposable chopsticks. According to the survey, nearly 93.94\% of them have used disposable chopsticks to varying degrees, and the never used only accounts for 6.06\%, which shows that college students' awareness of environmental protection is still lacking, and the current situation of green campus construction remains to be improved.

\section{E. Outlook on green campus}

The fifth part of the questionnaire mainly discusses suggestions and prospects of green campus construction. If measures are supported and agreed by respondents, they will be supported by the majority of college students, and the uncertainty will be greatly reduced.
The part is divided into the behavior standard, the environmental protection curriculum, the sewage system and so on. At the same time, it also gives respondents independent proposal options, and fully pays attention to the respondents' opinions and suggestions.

As for environmental codes of conduct, 177 respondents think it feasible to include them in college students' codes of conduct while 153 respondents don't think so, which indicates that a significant proportion of respondents disagree with the restrictions. For setting up environmental protection courses, 162 respondents hold positive views and the others do not, which shows that half of the college students are not interested in environmental protection courses, or have a idea that setting up environmental protection elective courses can't work. Besides, in terms of the establishment of a domestic sewage treatment system, 132 respondents consider it possible for schools to set up a sewage treatment system, while another 198 respondents can't agree it. On the one hand, they may think that schools do not have the funds or technology to complete the project; on the other hand, they also feel that schools have no awareness of sewage treatment.

IV. THE CAUSE ANALYSIS OF THE MAIN FACTORS IN THE GREEN CAMPUS CONSTRUCTION IN NORTHERN UNIVERSITIES

\section{A. Selection of analytical Methods}

Due to the large number of questionnaires and the complicated factors involved, this paper adopts the Principal Component Analysis method. Converting multiple variables into a few indexes, the Principal Component Analysis (PCA) is a simplified method, which is a kind of reduction treatment technology. In this way, both efficiency and main contradiction can be grasped. By means of the SPSS20.0 software, the paper descriptively studies the main factors affecting the green campus construction.

First of all, according to the content of questionnaires, from the perspective of college students, 8 variables are selected. The relevant variables are explained as follows:

The current situation of campus represents the students' general view; student education represents the current knowledge level of the college students; student consciousness is the degree of the university students' understanding of the importance of the green campus; self-behavior refers to the college students' participation in the green activities; behavior of others implies the related green behavior of other college students; campus planning is whether the overall planning of the school is reasonable; environmental markings refer to whether water-saving or garbage markings can effectively affect the college students; the environmental protection courses refer to whether the school make it be on the curriculum; the campus norms stand for the fact that whether it is feasible for the school to include the green behavior as the college students' behavior standard.

The current situation of campus is regarded as a dependent variable and other factors are independent variables.

Secondly, the dimension reduction analysis is carried out by using SPSS software, and TABLE III, TABLE IV and TABLE V are obtained. 
TABLE III. TEST OF KMO AND BARTLETT

\begin{tabular}{|c|c|c|}
\hline \multicolumn{2}{|c|}{ Sampling the Kaiser-Meyer-Olkin metric of adequacy } & .548 \\
\hline \multirow{3}{*}{ Sphericity Test of Bartlett } & Approximate chi-square & 137.381 \\
\cline { 2 - 3 } & $\mathrm{df}$ & 28 \\
\cline { 2 - 3 } & Sig. & .000 \\
\hline
\end{tabular}

According to the above TABLE III, it can be seen that the $\mathrm{KMO}$ test coefficient is equal to $0.548>0.5$, and $\mathrm{p}<0.05$, which means that the questionnaire has structural validity and it can conduct factor analysis.

TABLE IV. TOT AL VARIANCE OF EXPLANATION

\begin{tabular}{|c|c|c|c|c|c|c|c|c|c|}
\hline \multirow{2}{*}{ 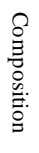 } & \multicolumn{3}{|c|}{ Initial eigenvalue } & \multicolumn{3}{|c|}{ Extract square sum load } & \multicolumn{3}{|c|}{ Rotation square sum loading } \\
\hline & Total & $\begin{array}{c}\% \text { of } \\
\text { variance }\end{array}$ & $\begin{array}{c}\% \text { of } \\
\text { Accumulation }\end{array}$ & Total & $\begin{array}{c}\% \text { of } \\
\text { variance }\end{array}$ & $\begin{array}{c}\% \text { of } \\
\text { Accumulatio } \\
n\end{array}$ & Total & $\begin{array}{c}\% \text { of } \\
\text { variance }\end{array}$ & $\begin{array}{c}\% \text { of } \\
\text { Accumulation }\end{array}$ \\
\hline 1 & 1.679 & 20.994 & 20.994 & 1.679 & 20.994 & 20.994 & 1.623 & 20.290 & 20.290 \\
\hline 2 & 1.275 & 15.937 & 36.931 & 1.275 & 15.937 & 36.931 & 1.183 & 14.792 & 35.082 \\
\hline 3 & 1.061 & 13.262 & 50.193 & 1.061 & 13.262 & 50.193 & 1.132 & 14.144 & 49.226 \\
\hline 4 & 1.012 & 12.653 & 62.846 & 1.012 & 12.653 & 62.846 & 1.090 & 13.620 & 62.846 \\
\hline 5 & .917 & 11.459 & 74.305 & & & & & & \\
\hline 6 & .833 & 10.409 & 84.714 & & & & & & \\
\hline 7 & .630 & 7.877 & 92.591 & & & & & & \\
\hline 8 & .593 & 7.409 & 100.000 & & & & & & \\
\hline
\end{tabular}

Extraction method: principal component analysis.

According to TABLE IV, the principal component extraction method can be used to classify 8 variables into 4 variables under the premise that the eigenvalue is greater than 1.

TABLE V. ROT ATION COMPONENT MATRIX

\begin{tabular}{|c|c|c|c|c|}
\hline & \multicolumn{4}{|c|}{ Composition } \\
\hline & 1 & 2 & 3 & 4 \\
\hline Student education & -.085 & .053 & .857 & -.193 \\
\hline Student consciousness & .082 & .197 & -.144 & .728 \\
\hline Self-behavior & .710 & .104 & -.179 & .224 \\
\hline Behavior of others & -.056 & .772 & .165 & .126 \\
\hline Environmental markings & .635 & .160 & .017 & -.486 \\
\hline Campus planning & .719 & -.083 & .107 & .038 \\
\hline $\begin{array}{l}\text { The environmental } \\
\text { protection courses }\end{array}$ & .417 & -.176 & .533 & .466 \\
\hline Campus norms & .088 & .686 & -.146 & .002 \\
\hline
\end{tabular}

Thirdly, it can be shown in TABLE V, self-behavior, environmental markings and campus planning can be classified as the first category, others' behavior and campus norms can be classified as the second category, students' education and the environmental protection courses can be classified as the third category, while students' consciousness is classified as the last category.

Finally, sort the main factors. In the first principal component, campus planning accounts for the largest proportion, reaching $71.9 \%$. In the second principal component, behavior of others achieves the largest proportion of all factors, up to $77.2 \%$. In the third principal component, student education accounts for $85.7 \%$. In the fourth component, the proportion of student consciousness is the highest, covering $72.8 \%$. In a word, the main influencing factors are campus planning, the behavior of others, student education and student consciousness.

\section{ANALYSIS ON THE PROBLEMS EXISTING IN THE CONSTRUCTION OF GREEN CAMPUS}

\section{A. Unreasonable campus planning and fewer students' environmental protection behavior}

At present, due to cost considerations, with some imperfect basic energy-saving and emission reduction facilities, most universities are old or built in the suburbs, where the science and convenience of campus remains to be discussed. In addition, the environmental protection behavior of college students is also related to campus construction. For example, if schools buildings such as teaching buildings, dormitories and canteens are scientifically designed, the takeout phenomenon will be reduced and the use of disposable chopsticks will be reduced, too.

\section{B. Ignorance of Environmental markings and imperfection of the rules and regulations}

Nowadays, environmental markings can be found everywhere in the school, but they are less helpful. The phenomenon of wasting water resource is still common, and the behavior of treading lawns is not uncommon. As for the rules and regulations, the school system has not changed for many years, which may be difficult to satisfy the requirements of the green campus, and the behavior of college students will 
be more or less guided by the rules and regulations. If schools do not attach importance to the rules and regulations, then students will lower their own requirements.

\section{Few environmental courses and green activities}

Most colleges generally pay attention to the cultivation of their own professional knowledge ability; basically do not set up the related environmental protection curriculum, which is extremely disadvantageous to the popularization of green campus knowledge. What's more, the college student organization organizes few activities on the theme of green campus, which does not greatly mobilize college students, so the formal propaganda can't play a substantial role.

\section{Lack of environmental awareness and negative external radiation}

College students have no consciousness of environmental protection and resource saving, which is a great danger to the green campus construction. Consciousness not only affects one's own behavior, but also exerts a subtle influence on others. In this way, if its adverse effect gradually expands, there will be a loss to schools. Even though college students are aware that some behavior is not correct, they may tend to pursue self-interests and ignore social benefits because of opportunity cost and "free-rider" mentality.

\section{CONCLUSION}

In the perspective of college students, there are mainly four factors affecting the green campus construction. And it is in the absence of attention paid to the factors that there are many problems in universities. All in all, college students should play an important role in the green campus construction, and their green thinking formed on campus will also effectively improve the overall social environment.

\section{REFERENCES}

[1] Jun Chen. To establish Green University and take the path of healthy and Sustainable Development [J]. China's higher education in 2012, 22: 9-11. (In Chinese)

[2] Qi Wu, Ling Nie. Reflections on Several Problems in the Construction of "Green Campus" [J]. Agricultural Science and Technology and Information (Modern Landscape Architecture) in 2010, (07):13-14. (In Chinese)

[3] Yujun Wang, Zhiming Chen. Study on the Connotation and Strategy of Green Campus Construction [J]. Shandong Agricultural Education in 2008, 4: 6-10. (In Chinese)

[4] Minjian Wang. Research on University Green Campus Construction [J]. Journal of Hunan Medical University (Social Science Edition) in 2010, 2 : 179-180. (In Chinese)

[5] Huifeng Tian, Jie Lin. Existing Ways and Practices of Green Campus Construction [J]. Construction of Science and Technology in 2015, 24: 31-35. (In Chinese)

[6] Zhiqiang Wu, Zisong Wang. The Main Points and Evaluation Cases of "Green Campus Evaluation Standard" [J]. Construction of Science and Technology in 2013 6: 82-86. (In Chinese) 